\title{
プレストレスト鉄筋コンクリート曲げ部材における ひび割れ幅と仮想引張応力度との関係 \\ RELATIONSHIP BETWEEN CRACK WIDTH AND HYPOTHETICAL TENSILE STRESS OF PARTIALLY PRESTRESSED CONCRETE MEMBERS
}

\author{
李 文 英*1, 大野義照*2, 尚 自 端*1 \\ Wenying LI, Yoshiteru OHNO and Ziduan SHANG
}

\begin{abstract}
The estimation of crack width is one of the most important tasks in designing partially prestressed concrete (PPC)members. However, this task, which includes calculation of crack spacing, average steel stress etc., is very tedious using current existing procedures. In this paper, relationship between crack width and hypothetical tensile stress was derived in order to simplify control of crack width in reinforced conctrete and PPC members. The hypothetical tensile stress is calculated on the assumption that the entire section is still effective even after cracking has occurred. The instantaneous and long-term crack widths are calculated by using the PPC Recommendation of Architectural Institute of Japan. Factors which had been taken into account in developing procedure of this method are: concrete strength, ratio of reinforcement, depth of beam, concrete cover depth, prestress, shrinkage and creep.
\end{abstract}

Keywords: hypothetical tensile stress, crack width, PPC member, RC member 仮想引張忍力度，ひび割れ幅，プレストレスト鉄筋コンクリート，鉄筋コンクリート

1.はじめに

コンクリート構造物では耐久性などの観点から、ひび割れ幅の制 御が直接，あるいは間接的に行われている。直接ひび割れ幅を計算 して制御寸る場合は，曲げモーメントから鉄筋応力を計算し、次に 平均鉄筋ひずみを求め、さらに配筋状態を考慮してひび割れ間隔を 求める必要があり、複雑で面倒な計算を要する1)。2)。

一方，プレストレスト鉄筋コンクリート ( $\mathrm{PRC}$ ) 部材の曲げひび 割れ幅制御の簡便な方法として、ひび割れ幅と仮想引張応力度（ひ び割れ発生後も、全断面が有効として計算される引張縁応力度）と を関連づける方法がある。建築学会のプレストレストコンクリート $(\mathrm{PC})$ 設計施工規準・同解説 ${ }^{3)}$ に打计る P C 部材の長期応力に対寸る 設計は，フルプレストレスの場合引張縁の忘力度は需以下，パー シャルプレストレスの場合引張応力度は設計基準強度の $1 / 30$ 程度 以下に制御寸るように引張縁応力度の検討でなされるが，仮想引張 応力度による方法はその延長上に位置するものである。また、建築 学会プレストレスト鉄筋コンクリート（四種 PC）構造設計・施工指 針・同解説 ${ }^{1}$ ）(以下 PRC 指針と略記）では、この方法の考えを一部 取り入れ、 II t、II tb という種別を設けている。すなわちコンクリー 卜の引張応力度を引張強度あるいは曲げ引張強度まで許容し、その 灾力度に見合う鉄筋を用心筋として配置してひび割れが生じた場合、
その幅を $0.1 \mathrm{~mm}$ 以下に制御しようとするものである。

イギリスの規準 CP1104) でも仮想引張応力度法が用いられてい る。そこでは仮想引張応力度にコンクリート強度、部材せいおよび 鉄筋比が考慮されているが，曲げひび割れ幅と密接な関係を持って いるコンクリートのかぶり厚さや配筋状態、プレストレスなどは考 慮されていない。

本報では、PRC 指針解説の曲げひび割れ偪算定式を用いて，曲げ ひび割れ幅と仮想引張応力度との関倸を求め、コンクリート強度、 引張鉄筋比、鉄筋中心間隔、鉄筋径、コンクリートのかぶり厚さ、 プレストレス、付着クリープ、乾燥収縮などの仮想引張応力度に対 する影響を調べ、これらをパラメータとする初期 (瞬時) 及び長期 ひび割れ幅と仮想引張応力度との関係式を導いた。

2 . 仮想引張応力度とひび割れ幅との関倸

2.1 仮想引張応力度の定義

仮想引張応力度 $\sigma_{f}$ は、ひび割れが生じた後もひび割れが生じて いないと仮定して、次式により計算される曲㖣部材の引張縁応力度 である。

$$
\sigma_{f}=\frac{M}{Z}-\left(\frac{P}{A}+\frac{P \cdot e}{Z}\right)
$$

${ }^{* 1}$ 大阪大学大学院工学研究科建築工学専政 大学院生

*2 大阪大学大学院工学研究科建築工学専攻 教授. 工博
Graduate Student, Dept. of Architectural Engineering, The Graduate School of Engineering, Osaka Univ.

Prof., Dept. of Architectural Engineering, The Graduate School of Engineering, Osaka Univ., Dr. Eng. 
ここに、

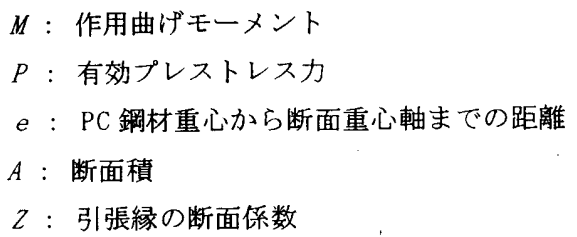

(1) 式はPRC 部材の算定式で、RC の場合 $P=0$ となる。

\section{2 仮想引張応力度の算出}

ひび割れ幅 Wavに対応する仮想引張応力度 $\sigma_{f}$ は次のようにして 求めた。ひび割れ幅Wavに対するひび割れ断面の鉄筋応力度 $\sigma_{t}$ を 算出し、鉄筋応力度 $\sigma_{t}$ 加ら抵抗曲げモーメント $M$ を求め、その $M$ を式（1）に代入して $\sigma_{f}$ を算出する。以下に用いた計算式などを 述べる。

1) 鉄筋応力度 $\sigma$, の算出

・初期 (瞬時) 平均ひび割れ幅 $W a v$ に対する鉄筋応力度 $\sigma$ ， PRC 指針解説のひび割れ幅算定式から、初期(瞬時) ひび割れ幅 Wavに対するひび割れ断面における鉄筋応力度 $\sigma$ ，の計算式として 次式が得られる。

$$
\sigma_{t}=\frac{W_{a v}}{l_{a v}} \cdot E_{s}+\frac{F_{t}}{p_{e}\left(2 \times 10^{3} W_{a v} / l_{a v}+0.8\right)}
$$

$$
\text { ここK, }
$$

$l_{a v}:$ 平均ひび割れ間隔

$E_{s}:$ 鉄筋のヤング係数

$F_{t}:$ コンクリート引張強度

$p_{e}:$ 有効引張鉄筇比 ${ }^{1}$

・長期ひび割れ幅 $W a v$ に対する鉄筋応力度 $\sigma_{t}$

ひび割れ幅は，鉄筋とコンクリート間の付着クリープによってコ ンクリートの協力作用が減少し平均鉄筋ひずみが増加することやひ び割れ間コンクリートの乾燥収縮によって時間の経過とともに増加 寸る5)、6)、7)。これらの要因を考慮した長期ひび割れ幅の計算式7)か ら，長期ひび割れ幅 $W a v$ に対寸る鉄筋応力度 $\sigma_{t}$ の計算式として (2’) 式が得られる。

$$
\sigma_{t}=\frac{w_{a \nu}-\varepsilon_{s h} l_{\alpha \nu}}{l_{a v}} \cdot E_{s}+C r \cdot \frac{F_{t}}{P_{e}\left[2 \times 10^{3}\left(w_{a v}-\varepsilon_{s h} l_{\alpha v}\right) / l_{\alpha v}+0.8\right]}
$$

ここに、 $\varepsilon_{s h}$ ：ひび割れ間コンクリートの乾燥収縮ひずみ

$\mathrm{Cr}$ ：付着クリープによるコンクリートの協力作用の减少 を評価する係数（初期の協力作用に対する比率）であり， 初期ひび割れ幅で付着クリープが生じていない場合は $\mathrm{Cr}$ $=1$ ，長期ひび割れ幅で付着クリープにより協力作用が $50 \%$ に減少した時は $C r=0.5$ である。

2) 鉄筋応力度 $\sigma$ ，に対応寸る曲げモーメント $M$ の算出

1) で求めた鉄筋応力度 $\sigma$, に対応寸る曲げモーメント $M$ は次式に より計算される。

$M=\frac{\sigma_{t}}{n_{s}(d-x)}\left(I_{c z}+n_{s} I_{s c z}+n_{p} I_{p x}+n_{s} I_{s x}\right)+P\left(d_{p}-x\right)$
ここに、

$x$ : 圧縮緣から中立軸位置までの距離

$n_{s}$ : 鉄筋のヤング係数のコンクリートのヤング係数に対する比

$n_{p}: \mathrm{PC}$ 鋼材のヤング倸数のコンクリートのヤング俰数に対寸る 比

$I_{c x}=b x^{3} / 3:$ 圧縮側コンクリートの中立軸に関する断面 2 次七 ーメント

$I_{s c x}=a_{c}\left(x-d_{c}\right)^{2}:$ 圧縮鉄筋の中立軸に関寸る断面 2 次モーメ ント

$I_{p x}=a_{p}\left(d_{p}-x\right)^{2}: \mathrm{PC}$ 鋼材の中立軸に関する断面 2 次モーメン 卜

$I_{s x}=a_{t}(d-x)^{2}:$ 引張鉄筋の中立軸に関する断面 2 次モーメン 卜

$b \quad$ ：はり幅

$a_{c} \quad:$ 圧縮鉄筋断面積

$a_{p}: \mathrm{PC}$ 鋼材断面糟

$a_{t} \quad$ : 引張鉄筋断面積

曲げモーメントMを(1) 式に代入すると、ひび割れ幅Wavに対応寸 る仮想引張応力度 $\sigma_{f}$ が求まる。

3. 基準モデル断面とパラメータ

3.1 基準モデル断面

基準モデル断面をPRC 指 針の設計例を参考にして 図1に示寸ような長方形 断面とする。鉄筋は異形 鉄筋上する。

$\mathrm{b}=40 \mathrm{~cm}, \mathrm{D}=80 \mathrm{~cm}$,

$\mathrm{F}_{\mathrm{c}}=300 \mathrm{kgf} / \mathrm{cm}^{2}, \mathrm{c}=5 \mathrm{~cm}$,

$a_{t}=20.28 \mathrm{~cm}^{2}$

(4-D25, $\left.\mathrm{p}_{\mathrm{t}}=0.69 \%\right)$,

$\mathrm{s}=9.17 \mathrm{~cm}, \mathrm{n}=4$,

$\sigma_{g}=0 \mathrm{kgf} / \mathrm{cm}^{2}$

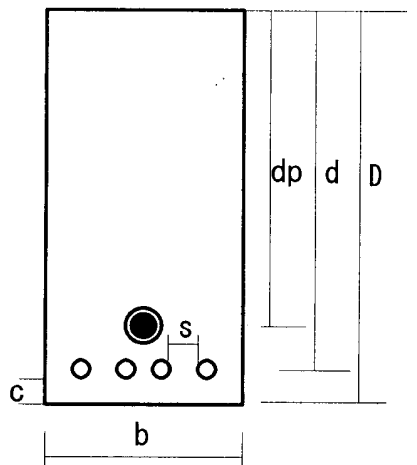

図 1 基準モデル断面

3. 2 パラメータ

1) コンクリート強度 $F_{c}: 200,300,400 ; 500,600 \mathrm{kgf} / \mathrm{cm}^{2}$

2) 引張鉄筋比Pt、鉄筋直径 $\phi$ および鉄筋本数 $\mathrm{n}$ ：異形鉄筋の 乎び名 $19 ， 22 ， 25 ， 29 ， 32 \mathrm{~mm}$ 、鉄筋本数 2 本から鉄筇中心間隔の制 限（呼び名の数值の 1.5 倍以上）加決まる一段配置可能本数。

3) 部材せい $D: 30 \mathrm{~cm} \sim 120 \mathrm{~cm}$

4) コンクリートのかぶり厚さc $: 3,4,5,6,7,8,9,10 \mathrm{~cm}$

5) 平均プレストレス $\sigma_{g}: 0,10,20,30,40 \mathrm{~kg} / \mathrm{cm}^{2}$

6）乾燥収縮ひずみ $\varepsilon_{s h}: 0,1,2,3,4\left(\times 10^{-4}\right)$

7）付着クリープによるコンクリートの協力作用の時間的減少 $\mathrm{Cr}: 1.0 \sim 0$

以上の基準モデル断面及びパラメータを用いて各種要因を考慮し た $W_{a v}-\sigma_{f}$ 関係を導いた。 


\section{4. 誘導過程及び結果}

\section{1 誘導過程}

\subsection{1 基淮断面}

基準モデル断面の $W_{a v}-\sigma_{f}$ 関係は図 2 のようになり，この関係を (4) 式の 1 次式で表すことにし定数を最小二乗法にて求めると (5) 式 が得られた。

$$
\begin{aligned}
& \sigma_{f}=k w_{a v}+\sigma_{f 0} \\
& \sigma_{f}=349 w_{a v}+10.1 \quad\left(k g f / \mathrm{cm}^{2}\right)
\end{aligned}
$$

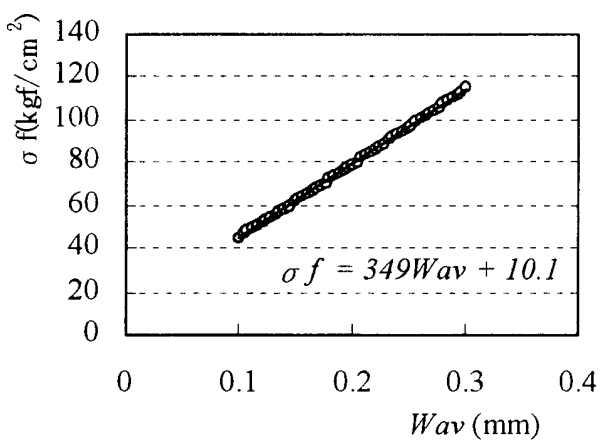

図 2 基準モデル断面の $W_{a v}-\sigma$ 関係

基準モデル断面の $W_{a v}-\sigma$ 関係を基にし、各パラメータの影響係 数を求めるために式（4）を次のように表す。

$$
\begin{aligned}
& \sigma_{f}=k \sigma_{f 0 s} \frac{1}{w_{a v 0}} w_{a v}+\sigma_{f 0} \\
& k=k_{1} k_{2} k_{3} \ldots . . . \\
& \sigma_{f 0 s}=34.9 \mathrm{kgf} / \mathrm{cm}^{2} \\
& w_{a v 0}=0.1 \mathrm{~mm} \\
& \sigma_{f 0}=\sigma_{f 0 i} m_{1} m_{2} m_{3} \ldots \\
& \sigma_{f 0 i}=10.1 \mathrm{kgf} / \mathrm{cm}^{2}
\end{aligned}
$$

$k_{1}, k_{2}, k_{3}$ などは各パラメータの一次式(6)の傾きへの影響倸数 である。 $\sigma_{f 0 s} 、 \sigma_{f 0 i}$ はそれぞれ基準モデル断面のひび割れ幅 Wav=0. $1 \mathrm{~mm}$ のときの傾きおよび綖軸切片である。 $m_{1}, m_{2}, m_{3}$ などは 各パラメータの切片への影響係数である。

\subsection{2 コンリート圧縮強度}

基淮断面において，コンリート圧縮強度のみを变化させて，コン クリート圧縮強度の $W_{a v}-\sigma$, 関倸八の影響を調バた結果, 図 $3 の よ$ うな関係が得られた。

この関係を 1 次式で近似しコンリート王縮強度の直線の傾きと縦 軸切片一の影響をみると，切片への影響は大きいが傾きへの影響は 小さい。そこで, コンクリート引張強度 $F_{t}$ と切片との関係を調べる 上, 図4のように線形関倸が得られた。これを最小二乗法により近 似し、コンクリート引張強度による影響係数 $m_{(F t)}$ を求めた。なお， コンクリートの引張強度は圧縮强度の0．07 倍としている ${ }^{1) 。}$

$$
\begin{aligned}
& m_{(F t)}=1.03 F_{t}^{\prime}-0.03 \\
& \text { ここで, } \quad F_{t}^{\prime}=\frac{F_{t}}{F_{t 0}}=\frac{F_{t}}{21}
\end{aligned}
$$

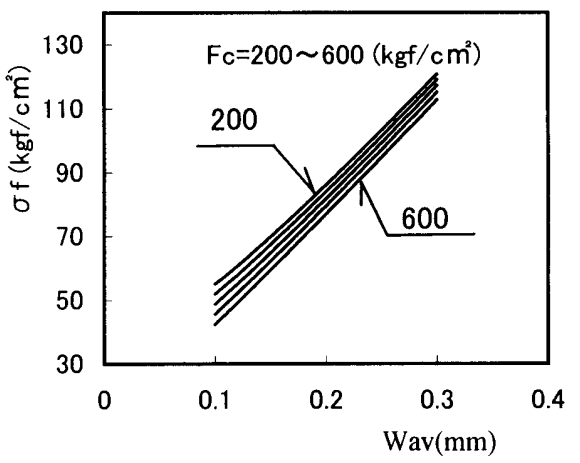

図 3 コンリート压縮強度と $W_{a v}-\sigma_{f}$ 関係

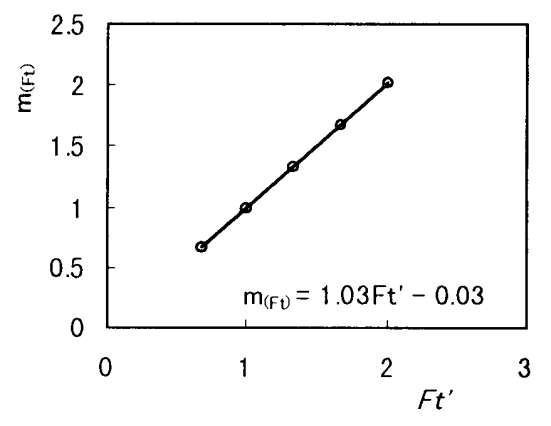

図 $4 m_{(F t)}$ と $\mathrm{Ft}^{\prime}$ の関係

\section{1 .3 引張鉄筋}

基準モデル断面に扔いて鉄筋の呼び径 $\phi$ と本数 $\mathrm{n}$ を変化させて求 めた $w_{a v}-\sigma$ 関係を図 5 に示寸。

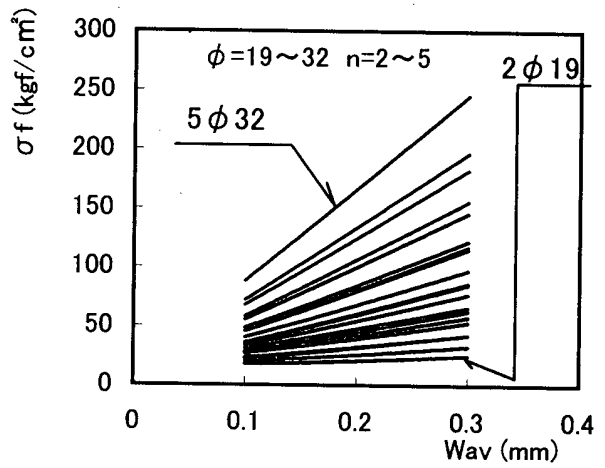

図 5 鉄筋径 $\phi$ 及び本数 $\mathrm{n}$ と $W_{a v}-\sigma$, 関倸

この関係を一次式に近似し，その傾きと鉄筋比 $p_{t}$ との関倸を鉄筋 径 $\phi$ 毎に整理すると図 6 が得られた。図6において各線の傾きはほ ぼ等しく, 縦軸の切片が鉄筋径 $\phi$ によって異なることを考慮して次 式を得た。 


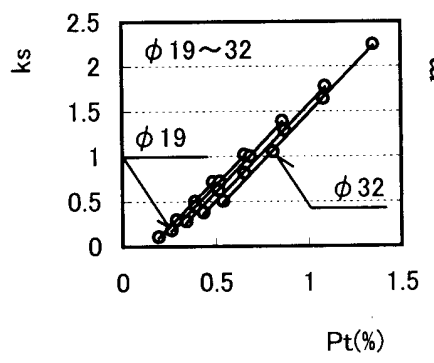

図6 $p_{t}, \phi$ の傾きへの影響

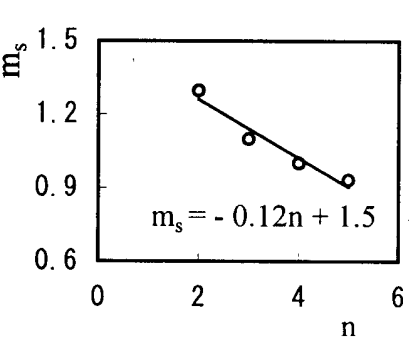

図7nの切片への影響

$$
\begin{aligned}
k_{s} & =2.15 p_{t}-0.70 \phi^{\prime}+0.22 \\
\text { ここに } \quad p_{t} & =100 a_{t} / b d \quad(\%) \\
\phi^{\prime} & =\frac{\phi}{\phi_{0}}=\frac{\phi}{2.5}
\end{aligned}
$$

また、図 5 の直線の切片に対する影響は図 7 のように線形関係に なり、これを最小二乗法により近似し, 次の切片への影響係数を得 た。

$$
m_{s}=-0.12 n+1.5
$$

\subsection{4 部材せい及びコンクリートかぶり厚さの影響}

コンリート压縮强度の影響の検討と同様な方法を用いて, 部材 せいD及びコンクリートかぶり厚さcの影響を調ぐ, 以下の上うな 関係式在得た。

$$
\begin{aligned}
k_{D} & =0.69 D^{\prime}+0.31 \\
k_{c} & =-0.76 c^{\prime}+1.76 \\
m_{c} & =1.2 c^{\prime}-0.2 \\
\text { ここに, } \quad c^{\prime} & =\frac{c}{c_{0}}=\frac{c}{5} \\
D^{\prime} & =\frac{D}{D_{0}}=\frac{D}{80}
\end{aligned}
$$

\subsection{5 プレストレスの影響}

プレストレスに関連している要因はPC 鋼材の断面積, プレストレ ス力 $P$ 及び $\mathrm{PC}$ 鋼材の偏心距離 $e$ である。PC 鋼材の断面積はひび割 れ間隔及び銅材の応力増分に影響するが，併用されている鉄筋の影 響に比べて，その影響は小さい1。すなわち，PC 鋼材の断面積の仮 想応力度への影響は小さいので無視できる。プレストレスカ $P$ 及び $\mathrm{PC}$ 鋼材偏心距離 $e$ の影響を調べるため, 次の検討を行った。

式(1)に式 (3) を代入寸ると, 次式が得られる。

$$
\sigma_{f}=\frac{\sigma_{f}}{Z \cdot n_{s}(d-x)}\left(I_{c z}+n_{s} I_{s c x}+n_{p} I_{p x}+n_{s} I_{s x}\right)+P\left(d_{p}-x\right) / Z-\left(\frac{P}{A}+\frac{P e}{Z}\right)
$$

ここに $\mathrm{Z}=\mathrm{bD}^{2} / 6, \quad \mathrm{~A}=\mathrm{bD}, \quad \mathrm{d}_{\mathrm{p}}=\mathrm{D} / 2+\mathrm{e}$

(7) 式を整理すると次式が得られる。
$\sigma_{f}=\frac{\sigma_{f}}{Z \cdot n_{s}(d-x)}\left(I_{c z}+n_{s} I_{s c x}+n_{p} I_{p x}+n_{s} I_{s x}\right)+\frac{2 P}{A}-\frac{P x}{Z}$

（8）式中でプレストレスと関連しているのは中立軸位置 $x$ 及びプ レストレスカPのみである。PC 鋼材断面積の影響は小さいので無視 寸ると, 中立軸位置 $x$ はPC 鋼材偏心距離 $e$ に影響されない。この ことから, 仮想引張応力度は $\mathrm{PC}$ 鋼材偏心距離 $e$ とは関係がなく，プ レストレスカだけの影響を受けるといえる。

平均プレストレス $\left(\sigma_{g}=P / A\right)$ の $W_{a v}-\sigma_{f}$ 関倸一の影響を調 ベると図8のようになり、この関倸を最小二乗法によって線形近似 した。傾きに対する影響は小さく，切片に対寸る影響は図9のよう になり、同図から次の関係式が得られた。

$$
\triangle m p=1.0 \sigma_{g}
$$

この関係は基準モデル断面において得られた結果であり，基準モ デル断面の鉄筋量は一般のPRC断面に対しては大きめと考えられる ので，基淮モデル断面において鉄筋を徐々に減少させて，プレスト レスカによる切片への影響を調べ，以下のような結果を得た。

$$
\begin{array}{ll}
2 \phi 2.5\left(p_{t}=0.36 \%\right): & \Delta m p=1.2 \sigma_{g} \\
2 \phi 2.2\left(p_{t}=0.26 \%\right): & \Delta m p=1.3 \sigma_{g}
\end{array}
$$

通常のPRC 断面の鉄筋量を考慮して，簡単化のためにプレストレ スによる切片に対寸る影響を以下のようにする。

$\Delta m p=1.3 \sigma_{g}$

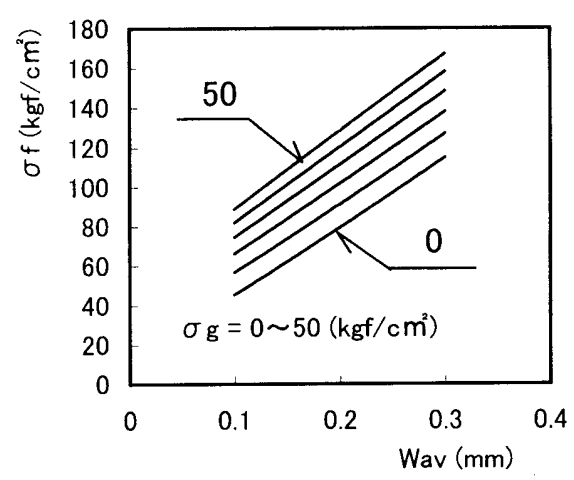

図 8 プレストレスと $W_{a v}-\sigma_{f}$ 関係

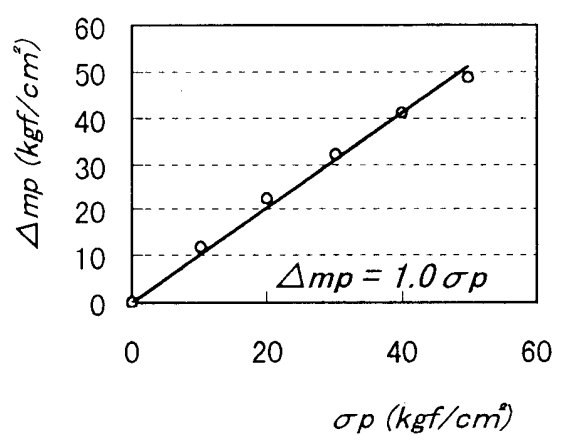

図 9 モデル断面の $\sigma \mathrm{g}-\Delta \mathrm{mp}$ 関倸 


\subsection{6 付着クリープの影響}

次に長期ひび割れ幅について検討する。前述のように鉄筋とコン クリート間の付着クリープによってひび割れ幅は増加する。上述の 要因の影響の検討と同じ手法で (2') 式を用いて付着クリープの影響 を調べた。

図 10 は $C r$ が 1 から 0 まで変化する時の $w_{a v}-\sigma_{f}$ 関係を表してい る。付着クリープの傾きへの影響は無視出来るほど小さく, 切片へ の影響のみを考慮した(図 11 参照)。

$$
m_{C r}=C r
$$

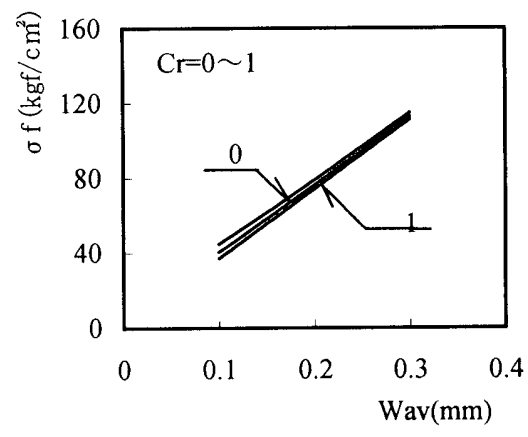

図 10 クリープ低减係数 $C r$ と $w_{a v}-\sigma_{f}$ 関倸

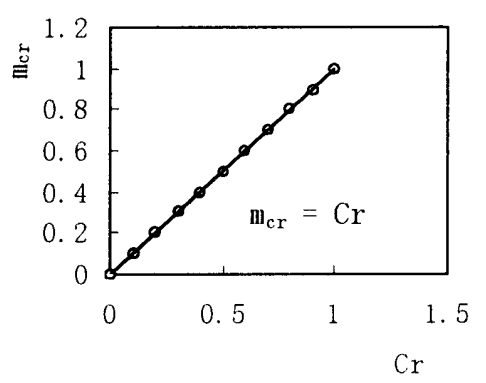

図 11 クリープ低減係数 $C r$ の切片人の影響

\subsection{7 乾燥収縮の影響}

長期ひび割れ幅への乾燥収縮の影響を考慮する7) ため、式 (2’) を用いて検討を行った。ただし式(2’)において Cr=1.0とする。

式(2’)は式(2)を $\varepsilon_{s h} l_{a v}$ だけ $w_{a v}$ 方向に平行移動した $w_{a v}-\sigma_{f}$ 関 係となるので、 $w_{a v}-\sigma$ 関係におうる直線の傾きは初期ひび割れと 同じ值となる。従って、乾燥収縮の影響を $w_{a v}-\sigma$ 関倸における、 切片に対する各パラメータの影響を次式のように表して調べた。

$$
\Delta \sigma_{f 0 s h}=\sigma_{f 0 s h} \times N 1 \times N 2 \times N 3 \times N 4 \ldots \ldots .
$$

$\sigma_{f 0 s h}$ は乾燥収縮 $\varepsilon=0.0002$ による切片に対する増分である。 $N 1, N 2, N 3$ などは乾燥収縮による各要因の仮想引張応力度への影 響倸数。

$\varepsilon_{s h}=0$ の基準断面に対して $\varepsilon_{s h}=0.0002$ 時 :

$$
\sigma_{f}=349 w_{a v}-2.4
$$

式(4) 及び(10)から， $\sigma_{f 0 s h}=-12.5 \mathrm{kgf} / \mathrm{cm}^{2}$ が得られる。このと

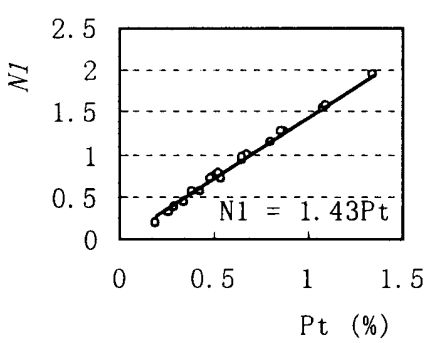

図 12 鉄筋比の乾燥収縮

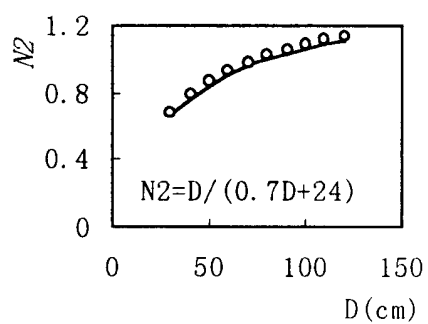

図 13 梁せいDの乾燥収縮

分一の影響
き、切片増分 $\Delta \sigma_{f 0 \text { sh }}$ に影響を及ぼすパラメータについて調べたとこ 万, 切片增分 $\Delta \sigma_{\text {fosh }}$ に影響するのは図 $12 ， 13 ， 14$ に示すように,

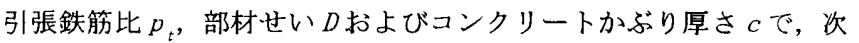
式のように表れされる。

$$
\begin{aligned}
& N I=1.43 p_{t} \\
& N 2=D /(0.7 D+24)=D^{\prime} /\left(0.7 D^{\prime}+0.3\right) \\
& N 3=-0.25 c^{\prime}+1.25
\end{aligned}
$$

上式は $\varepsilon_{s h}=0.0002$ に対して導いた結果である。次に乾燥収縮 ひずみ ${ }_{s h}$ を変化させると, 図 15 のようになる。

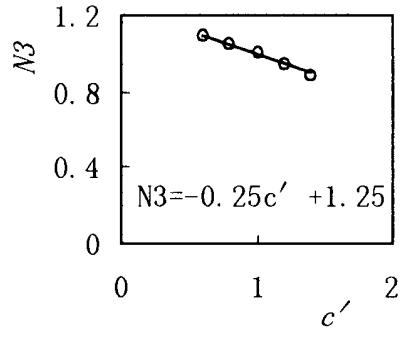

図 14 かぶり厚さ $\mathrm{c}$ の乾燥収縮 增分一の影響

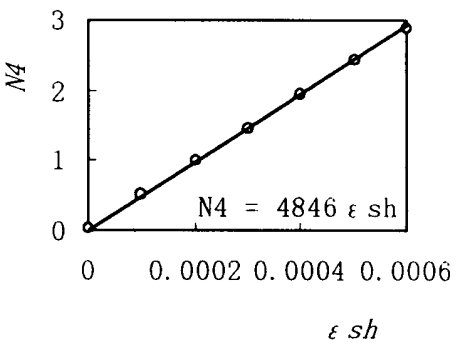

図 15 乾燥収縮ひずみの 乾燥収縮增分一の影響
この図から影響係数 N4がえられる。

$$
\begin{aligned}
N 4 & =4846 \times \varepsilon_{s h} \\
& \fallingdotseq 0.5 \times 10^{4} \times \varepsilon_{s h}
\end{aligned}
$$

以上の乾燥収縮による切片増分 $\Delta \sigma_{f 0 s h}$ 一の影響の検討結果をま とめると次のようになる。

$$
\begin{gathered}
\sigma_{f 0 s h}=-12.5 \mathrm{~kg} / \mathrm{cm}^{2} \\
N 1=1.43 p_{t} \\
N 2=D^{\prime} /\left(0.7 D^{\prime}+0.3\right) \\
N 3=-0.25 c^{\prime}+1.25 \\
N 4=0.5 \times 10^{4} \times \varepsilon_{s h} \\
\Delta \sigma_{f 0 s h}=\sigma_{f 0 s h} \times N 1 \times N 2 \times N 3 \times N 4 \\
=-6.3 \times 10^{4} \times \varepsilon_{s h} \times N 1 \times N 2 \times N 3
\end{gathered}
$$




\section{2 結果}

4.1 で得られた結果をまとめると, 平均ひび割れ幅 Wav と仮想引 張応力度 $\sigma_{f}$ の関保式は以下のようになる。

$$
\sigma_{f}=k \sigma_{f 0 s} \frac{1}{w_{a v 0}} w_{a v}+\sigma_{f 0}
$$

ここに

$$
\begin{aligned}
& \sigma_{f 0 s}=34.9 \mathrm{kgf} / \mathrm{cm}^{2} \\
& w_{a v 0}=0.1 \mathrm{~mm} \\
& k^{\prime} k_{s} k_{c} k_{D} \\
& k_{s}=2.15 p_{t}-0.70 \phi^{\prime}+0.22 \\
& k_{D}=0.69 D^{\prime}+0.31 \\
& k_{c}=-0.76 c^{\prime}+1.76 \\
& \sigma_{f 0}=\sigma_{f 0 i} m_{(F t)} m_{s} m_{c} m_{C r}+\Delta m p+\Delta \sigma_{f 0 s h} \\
& \sigma_{f 0 i}=10.1 k_{g f} / \mathrm{cm}^{2} \\
& m_{(F t)}=1.03 F_{t}^{\prime}-0.03 \\
& m_{s}=-0.12 n^{\prime}+1.5 \\
& m_{c}=1.2 c^{\prime}-0.2 \\
& m_{C r}=C r \\
& \Delta m_{p}=1.3 \sigma_{g} \\
& \Delta \sigma_{f 0 s h}=-6.3 \times 10^{4} \times{ }_{s h} \times N I \times N 2 \times N 3^{\prime} \\
& \quad N 1=1.43 p_{t} \\
& \quad N 2=D^{\prime} /\left(0.7 D^{\prime}+0.3\right) \\
& \quad N 3=-0.25 c^{\prime}+1.25
\end{aligned}
$$

なおく，ひび割れ幅制御設計では最大ひび割れ幅 $w_{\text {max }}$ を制御対象 とする。 $\mathrm{PRC}$ 指針では $w_{\max }=1.5 w_{a v}$ としているので, $w_{\max }$ と $\sigma_{f}$ と の関倸を求めると, 次式のようになる。

$$
\begin{aligned}
\sigma_{f} & =k \sigma_{f 0 s} \frac{1}{w_{a v 0}} w_{a v}+\sigma_{f 0} \\
& =k \sigma_{f 0 s} \frac{1}{w_{a v 0}} \frac{w_{\text {max }}}{1.5}+\sigma_{f 0} \\
& =k \sigma_{f 0 s} \frac{1}{1.5 w_{a v 0}} w_{\max }+\sigma_{f 0}
\end{aligned}
$$

\section{5. 適合性の検討}

式(11)の適合性を検㭙するために，PRC 指針解説のひび割れ幅算 定式によりひび割れ幅に対する曲げモーメントを計算し，（1）式よ り求めた仮想引張応力度と式 (11) による仮想引張态力度を比較し た。比較断面は, 部材せい $50 \mathrm{~cm} \sim 120 \mathrm{~cm}$, かぶり厚さ $5 \mathrm{~cm} \sim 7 \mathrm{~cm}$, 引張鉄筋 2 D $16 \sim 5 \mathrm{D} 29$, コンクリート圧縮強度 $200 \mathrm{kgf} / . \mathrm{cm}^{2} \sim$ $400 \mathrm{kgf} / \mathrm{cm}^{2}$, 平均プレストレス $0 \mathrm{kgf} / \mathrm{cm}^{2} \sim 25 \mathrm{kgf} / \mathrm{cm}^{2}$ の範囲
のPRC 及びRC の 24 の断面である。計算結果を図 $16 ， 17$ に示す。横 軸はPRC 指針解説のひび割れ幅算定式による仮想引張応力度であり ，縦軸は提案式による仮想引張応力度である。

図 16 は $C r=1, \varepsilon_{s h}=0$ の初期（瞬時）ひび割れ幅の比較, 図 17 は付着クリープ $(C r=0.5)$ と乾燥収縮 $\left(\varepsilon_{s h}=0.0002\right)$ を考慮した長 期ひび割れ幅の比較で，いずれもWav $=0.2 \mathrm{~mm}$ である $(0.1 \mathrm{~mm}$ 及び $0.3 \mathrm{~mm}$ についても $0.2 \mathrm{~mm}$ の場合とほぼ同じ結果が得られている)。

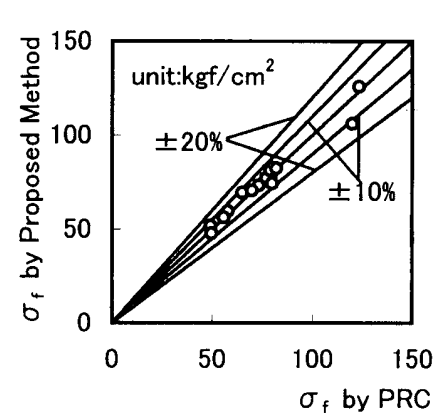
に対する比較
図 16 初期 (瞬時) ひび割れ幅 $0.2 \mathrm{~mm}$

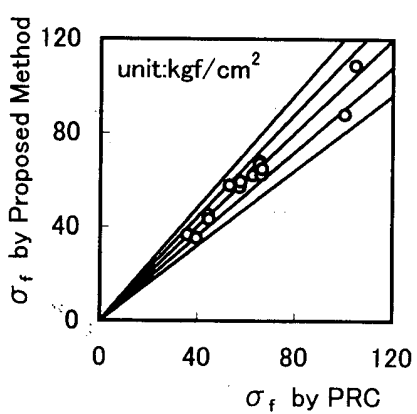

図 17 長期ひび割れ幅 $0.2 \mathrm{~mm}$ に対する比較
これらの図から，提案式による仮想引張応力度はPRC 指針により 直接算出した仮想引張忘力度の土10\%の範囲内にあることがわかる。

次に，提案式による仮想引張応力度と、CEB-78 の曲げひび割れ幅 算定式から曲げモーメントを計算し，（1）式より求めた仮想引張応 力度と比較した。図 $18 ， 19$ にそれぞれ平均ひび割れ幅 $0.2 \mathrm{~mm}$ 及び 0. $3 \mathrm{~mm}$ に対寸る比較を示す。いずれも初期（瞬時）ひび割れ幅であ る。
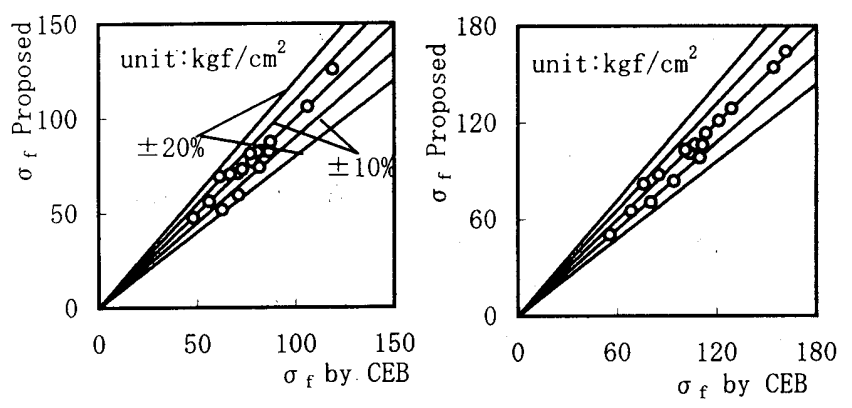

図 $18 w_{a v}=0.2 \mathrm{~mm}$ に対する提 図 $19 w_{a v}=0.3 \mathrm{~mm}$ に対する提案 案式と CEB78 の比較 式と CEB78 の比較

これらの図から，提案式による仮想引張応力度と CEB-78による 仮想引張応力度とはよく一致しており，提案した仮想引張応力度は CEB-78 のひび割れ幅計算式にも対応していることがわかる。

また，CP110の仮想引張応力度との比較も行った。CP110 は制御 目標值を対象としているので，最大の瞬時ひび割れ幅 $w_{\max }$ に対寸 る仮想引張応力度を求めた。図 20,21 に示すように、全般的にCP110 の值は提案式による值より大きく（提案式による值の約 2 倍と大き い場合もある)，ひび割れ幅をかなり小さ目に評価していることにな る。 


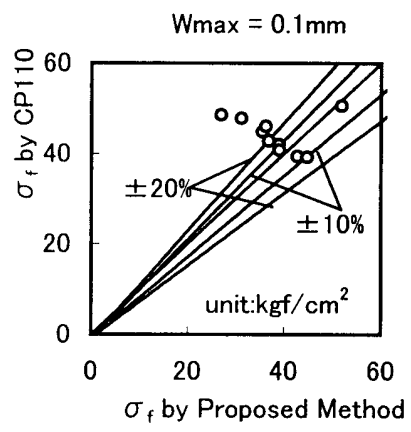

図 $20 w_{\text {max }}=0.1 \mathrm{~mm}$ に对する提

案式と CP110 の比較

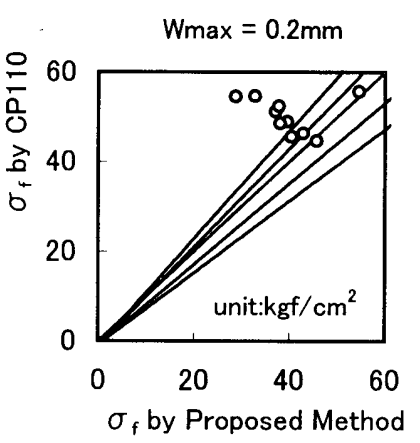

図 $21 w_{\text {max }}=0.2 \mathrm{~mm}$ に対する提

案式と CP110の比較

6.むすび

プレストレスト鉄筋コンクリート $(\mathrm{PRC})$ 部材及び鉄筋コンクリー ト $(\mathrm{RC})$ 部材の簡便な曲げひび割れ制御法として、仮想引張応力度と ひび割れ幅との関倸式を遒いた。仮想引張応力度はひび割れの発生 後も全断面有効として計算されるもので、PC 部材の長期応力に対寸 る設計と同じ手法で、すなわちコンクリートの縁応力度によってひ び割れ幅の検討を行うことが出来る。得られたひび割れ幅と仮想引 張応力度との関係式の特徵は次のとおりである。

1）初期 (瞬時) ひび割れ幅に対する、仮想引張応力度に影響する 要因は、鉄筋比、鉄筋径、鉄筋本数、コンクリート強度、コンクリー トのかぶり厚さ、プレストレスである。PC 鋼材の偏心距離は，PC 鋼 材応力の増分を考慮しない場合は仮想引張応力度に影響しない。

2）コンクリートの乾燥収縮及びひび割れ間コンクリートの付着ク リープが考慮されており、長期ひび割れ幅に対しても適用できる。

3）梁せい $50 \sim 120 \mathrm{~cm}$ 、引張鉄筋 2D-16〜5D-29、平均プレストレ ス $\sigma \mathrm{g} 0 \sim 25 \mathrm{kgf} / \mathrm{cm}^{2}$ の梁断面について、導いた $\sigma_{f}$ と $w_{a v}$ の関係 式から得た仮想引張応力度は、CEB-78のひび割れ幅算定式を用いて 計算した值ともよい一致をみた。CP110の仮想引張応力度以導いた 関係式による值の約 2 倍と大きい場合もある。

謝辞

本研究を進めるに際して、李振宝氏（(株) 耐震企画設計)、岩田樹 美氏（(株) NTTファシリテイーズ）の協力を得た。記して謝意を表 します。

\section{参考文献}

1）日本建築学会編：プレストレスト鉄筋コンクリート構造設計・ 施工指針・同解説、1986.1

2) CEB-FIP: CEB-FIP Model Code for Concrete Structures, 1978

3）日本建築学会編：プレストレストコンクリート設計施工規準 · 同解説、1998.11

4) British Standards Institution, Code of Practice for The Structural Use of Concrete, CP110 Part 1, p. 68, 1972

5）鈴木計夫、大野義照：プレストレスト鉄筋コンクリートはりの 曲げひびわれ幅に関する研究（その2）、日本建築学会論文報告

集、第 305 号、pp. 51-57、1981.7

6）大野義照、李振宝、鈴木計夫：持続荷重下における異形鉄筋上 コンクリート間の付着応力〜す心゙り関係、日本建築学会構造采 論文集、No.459、pp.111-120、1994.5

7）李振宝、大野義照、鈴木計夫：RC はりの長期ひび割れ幅に及ほ す付着クリープと乾燥収縮の影響、コンクリートエ学年次論文 報告集、Vol. 16、 No. 2、 pp. 407-412、1994

（1999年 2 月10日原稿受理，1999年 6 月 25 日採用決定） 